\title{
First Multi-GAS based characterisation of the Boiling Lake volcanic gas (Dominica, Lesser Antilles)
}

\author{
Rossella Di Napoli ${ }^{1, \star}$, Alessandro Aiuppa ${ }^{1,2}$, Patrick Allard ${ }^{3}$ \\ ${ }^{1}$ Università degli Studi di Palermo, Dipartimento di Scienze della Terra e del Mare (DiSTeM), Palermo, Italy \\ ${ }^{2}$ Istituto Nazionale di Geofisica e Vulcanologia, Sezione di Palermo, Palermo, Italy \\ ${ }^{3}$ Institut de Physique du Globe de Paris (IPGP), Paris, France
}

Article history

Received January 2, 2013; accepted October 7, 2013.

Subject classification:

Gases, Volcano monitoring, Instruments and techniques, Volcanic risk, Geochemical data.

\begin{abstract}
We used a Multi-component Gas Analyser System (Multi-GAS) to measure, for the very first time, the composition $\left(\mathrm{H}_{2} \mathrm{O}, \mathrm{CO}_{2}, \mathrm{H}_{2} \mathrm{~S}, \mathrm{SO}_{2}\right)$ of the volcanic gas plume issuing from the Boiling Lake, a vigorously degassing, hot $\left(T \sim 80-90^{\circ} \mathrm{C}\right)$ volcanic lake in Dominica, West Indies. The MultiGAS captured in-plume concentrations of $\mathrm{H}_{2} \mathrm{O}, \mathrm{CO}_{2}$ and $\mathrm{H}_{2} \mathrm{~S}$ were well above those typical of ambient atmosphere, while no volcanic $\mathrm{SO}_{2}$ was detected $(<0.05 \mathrm{ppm})$. These were used to derive the Boiling Lake plume characteristic ratios of $\mathrm{CO}_{2} / \mathrm{H}_{2} \mathrm{~S}(5.2 \pm 0.4)$ and $\mathrm{H}_{2} \mathrm{O} / \mathrm{CO}_{2}(31.4 \pm 6)$. Assuming that other volcanic gas species (e.g., $\mathrm{HCl}, \mathrm{CO}, \mathrm{H}_{2}, \mathrm{~N}_{2}$, etc.) are absent in the plume, we recalculated a (air-free) composition for the sourcing volcanic gases of $\sim 96.3 \% \mathrm{H}_{2} \mathrm{O}, 3.1 \% \mathrm{CO}_{2}$ and $0.6 \% \mathrm{H}_{2} \mathrm{~S}$. This hydrous gas composition is within the range of published gas compositions in the Lesser Antilles region, and slightly more $\mathrm{H}_{2} \mathrm{O}$-rich than obtained for the fumaroles of the nearby Valley of Desolation ( $~ 94.4 \%$ $\mathrm{H}_{2} \mathrm{O}, 4.7 \% \mathrm{CO}_{2}$ and $0.8 \% \mathrm{H}_{2} \mathrm{~S} ; \mathrm{CO}_{2} / \mathrm{H}_{2} \mathrm{~S}$ of $\left.\sim 5.7\right)$. We use our results, in tandem with the output of numerical simulations of gas scrubbing in the lake-water (performed via the EQ3 / 6 software), to derive new constraints on the degassing mechanisms at this poorly studied (but potentially hazardous) volcanic lake.
\end{abstract}

\section{Introduction}

The Lesser Antilles volcanic arc, in the West Indies, hosts a productive chain of active volcanoes [Wadge 1984] which devastation power has dramatically been brought to mind by the 1902 Mt. Pelée eruption in Martinique (30,000 casualties; Lacroix [1904]) and, more recently, by the still-ongoing Soufrière Hills (Montserrat) eruption started in 1995 [Druitt et al. 2002]. With most of its active volcanoes remaining dormant for centuries but still prone to erupt again in the future, and with a still-developing socio-economical structure with clear touristic vocation, the Lesser Antilles remain an area where a po- tentially high volcanic risk insists [Roobol and Smith 1989]. As dramatically evocated by the great controversies arisen during management of the 1975-76 seismo-volcanic crisis of La Soufrière in Guadeloupe (references in Komorowski et al. [2005]), a better understanding of past volcanic behaviour and presentday volcano setting is vital to correctly interpret any change in the status of historically active volcanoes, potentially heralding to an eruption.

Dominica has been, since the Miocene, the most productive (in terms of erupted volumes) volcanic island of the Lesser Antilles arc [Wadge 1984], and some of the most explosive eruptions (with depositional record) in the arc have occurred in this island [Sigurdsson 1972, Carey and Sigurdsson 1980, Sparks et al. 1980, Lindsay et al. 2003]. There is no report of magmatic eruptions in historical times in Dominica, however, and the island is today only partially covered by modern instrumental volcano monitoring networks. Whilst seismological information is largely available (Seismic Research Unit, University of the West Indies, Trinidad and Tobago; see Stasiuk et al. [2002], and Lindsay et al. [2003]), the geochemical monitoring network is far less developed, albeit hydrothermal manifestations are vast and widespread over the island [Joseph et al. 2011, and reference therein], and overall an expression of the island's still active volcanic nature.

The Boiling Lake (BL; Figure 1), located in the SEsector of the island (Figures 2 and 3), is the most impressive hydrothermal manifestation in Dominica. With its persistent vigorous steam discharges, its high temperature $\left(80-90^{\circ} \mathrm{C}\right.$ ) and acid environment ( $\left.\mathrm{pH}, 4-6\right)$ [Fournier et al. 2009], the BL is one of the most ex- 

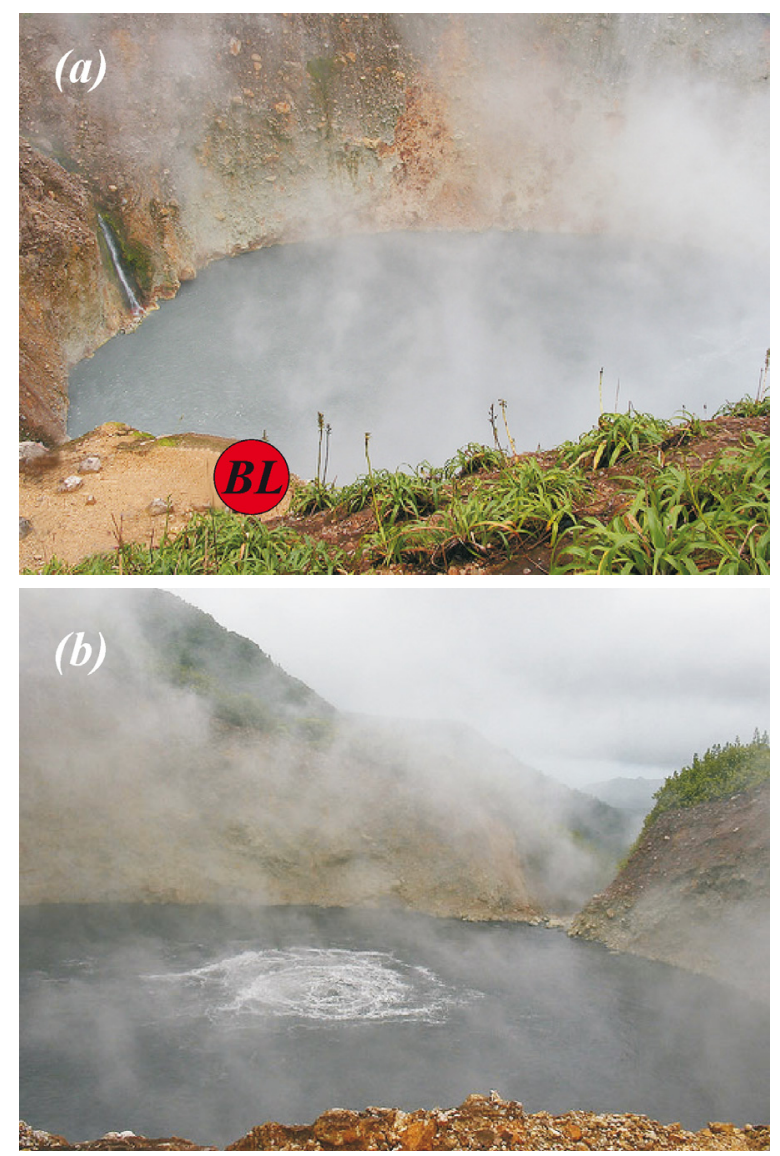

Figure 1. The Boiling Lake: (a) our Multi-GAS measurement site is indicated a BL; (b) vigorous gas bubbling in the lake's centre.

traordinary volcanic hot lakes in the world (the second largest after the Frying Pan Lake, New Zeeland; Vandemeulebrouck et al. [2008]). The BL has also been the theatre of the most recent volcanic phenomenologies on Dominica, such as a phreatic explosions in 1880 (described by Nicholls [1880a,b]) and a lethal $\mathrm{CO}_{2}$-gas release event in 1901 [Elliot 1938, Bell 1946].

A more recent phreatic explosion is reported to have occurred in 1997 in the Boiling Lake/Valley of Desolation area (Figure 3). While there have been previous reports on the chemical and isotopic compositions of lake-waters [Pedroni et al. 1999, Joseph et al. 2011], no information is presently available on the composition of the gas being discharged at the lake's surface, due to the inherent difficulties in direct gas sampling (gas discharges occur at the centre of a vigorously convecting hot lake).

Here, we report on the first characterisation of the BL gas manifestations, which we obtained by inplume gas observation with a Multi-GAS [Aiuppa et al. 2005] during a field expedition in late February 2012. We demonstrate the suitability of the MultiGAS as a technique to permanently monitor activity of the lake. We also use our results to derive new information on degassing features at this potentially hazardous lake.

\section{The study area}

\subsection{The Lesser Antilles volcanic arc}

The island of Dominica (Figure 2), located between Martinique, to the south, and Guadeloupe, to the north, belongs to the Lesser Antilles archipelago, which extends for $\sim 850 \mathrm{Km}$ from the Atlantic continental margin to the Greater Antilles.

The Lesser Antilles archipelago forms the currently active volcanic arc of a convergent margin, in which the north American Plate oceanic crust is being subducted underneath the Caribbean Plate, since the Oligocene, at a 2-3 cm/yr rate [Maury et al. 1990, Dixon et al. 1998, DeMets et al. 2000]. The Lesser Antilles islands describe a double arc, coalescent in the southern part and diverging into two branches in the northern sector, at the latitude of Dominica [Martin-Kaye 1969]. Volcanic activity has been concentrated on the eastern branch until the Miocene, since when it shifted to the western side of the arc [Bouysse 1984, Bouysse et al. 1990] in response to a major deformation event in the subducting plate. Because of this, the Benioff zone underneath the Lesser Antilles archipelago actually appears irregular, dipping $50-60^{\circ}$ to the north of Martinique, to then deepen in the southern part of the arc, to become vertical near Grenada Island [Wadge and Shepherd 1984, Feuillet et al. 2002]. The slab is supposed to be located at about $170 \mathrm{~km}$ depth underneath Martinique and Dominica; in this depth range, clusters of deep seismic events have been detected [Ruiz et al. 2011].

Volcanic rocks in the Lesser Antilles are dominantly andesites and dacites of calc-alkaline affinity. A progression from low-K tholeiitic products, to medium and high-K calc-alkaline and alkaline rocks, has been shown to occur from northern (Montserrat to Saba) to central (from St. Lucia to Guadeloupe) and southern (Grenada) parts of the arc [Sigurdsson et al. 1973, Brown et al. 1977, Hawkesworth and Powell 1980, Smith et al. 1980, Westercamp 1988]. This trend is associated to enrichment in incompatible elements and increase in radiogenic strontium and lead [Davidson 1986, White and Dupré 1986, Pedroni et al. 1999], suggesting either (i) assimilation of terrigenous sediment by the rising magma plus fractional crystallization [Davidson 1985, 1987, Smith et al. 1996, Thirlwall et al. 1996] or (ii) mixing of partially melted subducted sediments and primitive mantle in the Benioff zone [White and Dupré 1986, Westercamp 1988].

\subsection{Dominica}

Dominica is almost completely made up of volcanic rocks, with the exception of some minor conglomerates and corals along its west coast. Outcropping 


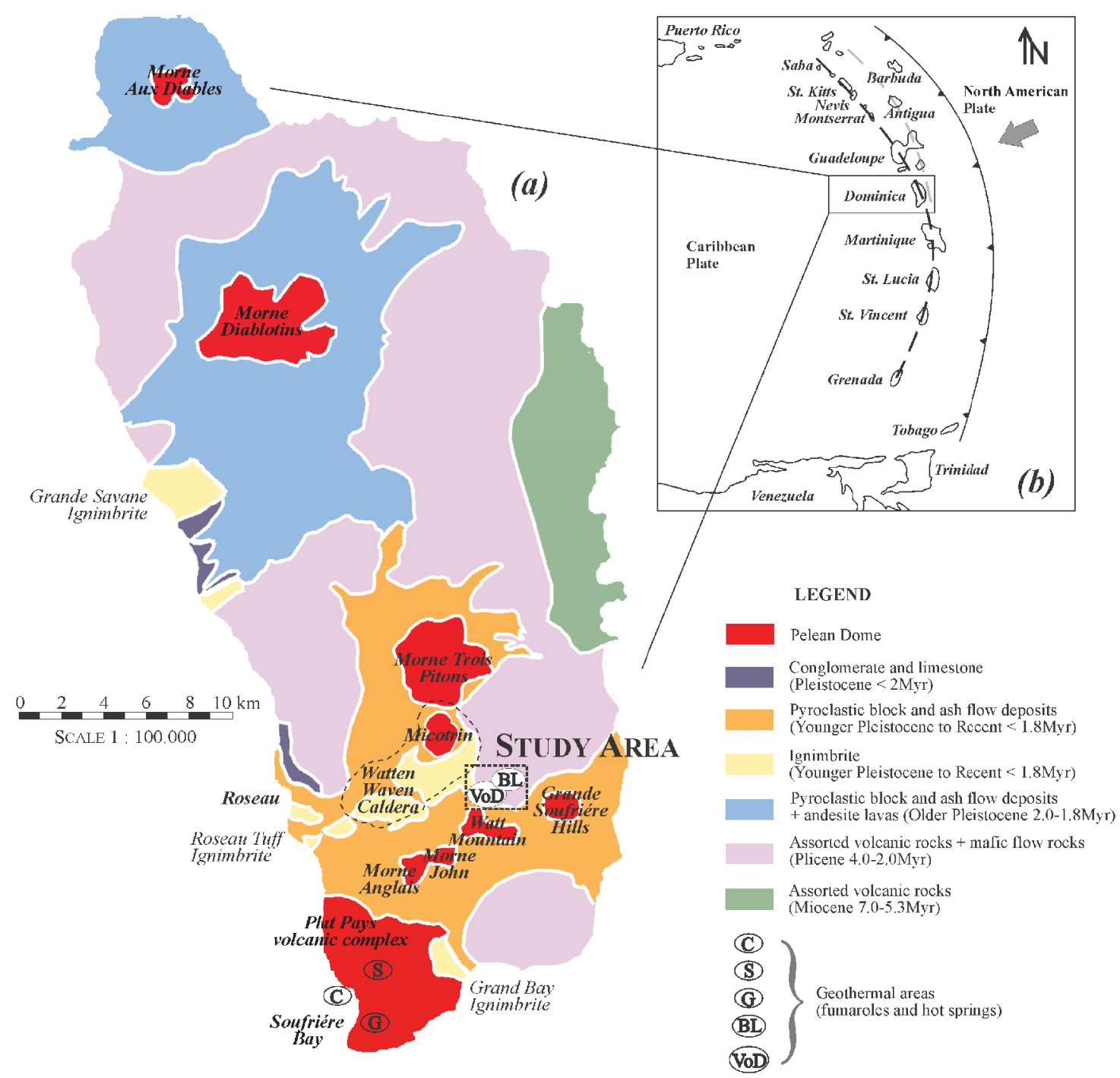

Figure 2. (a) Simplified geological map of Dominica (modified from Roobol and Smith [2005]); the inset (b) shows position of Dominica in the Lesser Antilles arc and simplified tectonic setting of the region (see text).

volcanites have been dated from Miocene to present [Demange et al. 1985, Monjaret 1985, Bellon 1988] (Figure 2). The cumulative erupted magma volume of $\sim 40 \mathrm{~km}^{3}$ [Wadge 1984] makes of Dominica the most productive volcanic island in the Lesser Antilles in the last $100 \mathrm{ka}$. Basaltic magmas were erupted in early volcanic activity stages (from Miocene to the Pliocene), while Pelean-type domes and pyroclastic deposits, ranging from andesitic to dacitic in composition, characterized volcanic activity in Pleistocene to Recent.

A key phase in the formation of present day Dominica is thought to have occurred in the Pliocene (4$2 \mathrm{Ma}$ ), when the bulk of the island was built up by several coalescent volcanoes. This activity overall led to edification of a large strato-volcano (Cochrane-Mahaut centre), which eroded remains are now mainly preserved in the southern-central portion of the island [Bellon 1988]. The Cochrane-Mahaut centre consisted of a basal (less than 3.7 Ma but more than 2.83 Ma old) unit of basaltic pillow lavas and submarine volcanic breccias, overlain by subaerial andesitic lava flows and inter-bedded pyroclastic deposits in its younger sections. After a probable break in volcanism, at about $2 \mathrm{Ma}$ (when well developed soils were formed), volcanic activity resumed and intensified in the Pleistocene, concentrating in the south-central part of the island during the last $1 \mathrm{Ma}$. Nine major pyroclastic flow deposits, the largest of which being the Roseau Tuff and the Grand Bay Ignimbrites [Lindsay et al. 2003, 2005], have been related to the activity of volcanic centres in the southern part of Dominica [Sigurdsson 1972, Lindsay et al. 2003, 2005]. The $\sim 30$ ka old Roseau Tuff was produced by the largest explosive eruption in the last $200 \mathrm{ka}$ of the Lesser Antilles [Carey and Sigurdsson 1980]. The eruption was sourced by either the Morne Trois Pitons/Micotrin lava domes [Sigurdsson 1972, Carey and Sigurdsson 1980, Sparks et al. 1980] or the Wotten Waven caldera [Demage et al. 1985]. The Roseau Tuff consists of a huge $\left(3 \mathrm{~km}^{3}\right)$ ignimbrite deposit, occasionally welded, filling a $\sim 8 \mathrm{~km}$ long valley 
up to the city of Roseau [Sigurdsson 1972, Sparks et al. 1980]. The Grand Bay Ignimbrites outcrop in the south-eastern sector of Dominica and have recently [Lindsay et al. 2003, 2005] been related to a $\sim 39$ ka old large-scale collapse event of the Plat Pays volcano, which ultimately led to formation of Soufrière bay. The Grand Savanne Ignimbrite (22-44 ka; Sparks et al. [1980]) is a pyroclastic deposit originated by Plinian eruption(s) of Morne Diablotins, the only volcanic centre of the northern part of Dominica active during the Pleistocene.

While there is no historical report of magmatic eruptions in Dominica, seven volcanoes, active in the last $10 \mathrm{ka}$, are considered likely to erupt again. The high eruption potential of Dominica is also supported by widespread geothermal activity [Joseph et al. 2011] and shallow seismicity (a major earthquake swarm was observed in 1998-2000 on the southern sector of Dominica; Stasiuk et al. [2002], Lindsay et al. [2003]). Low-temperature $\left(90-100^{\circ} \mathrm{C}\right)$ sulphur-rich fumaroles and hot springs are common in the Plat Pays volcanic complex area (Sulphur Springs, Galion fields and Champagne Beach) and in the Watten Wave caldera, in the SW-sector of the island [Joseph et al. 2011]. Hydrothermal fluid discharges are also abundant in the Valley of Desolation/Boiling Lake sector, where a number of hot springs, bubbling pools and fumaroles are hosted in a very small area $\left(0.5 \mathrm{~km}^{2}\right)$. Thermal waters in the Valley of Desolation area are generally acidic ( $\mathrm{pH}=1$ to 4 ), hot (temperatures from $74{ }^{\circ} \mathrm{C}$ to $98{ }^{\circ} \mathrm{C}$ ) and with a prevalent $\mathrm{Na}-\mathrm{SO}_{4}$ composition. They are interpreted [Joseph et al. 2011] as the result of steam-heating of meteoric fluids by rising $\mathrm{CO}_{2}-\mathrm{H}_{2} \mathrm{~S}$ rich hydrothermal vapours.

\subsection{The Boiling lake}

The Valley of Desolation/Boiling Lake region has been the theatre of two main phreatic explosions in 1880 [Nicholls 1880a,b] and, more recently, in 1997, and is a most likely potential source region for the next volcanic eruption in Dominica. Located at about $800 \mathrm{~m}$ of altitude, in a hill above the Valley of Desolation area (SE-sector), the Boiling Lake (Figure 1) has a volume of $\sim 10^{4} \mathrm{~m}^{3}$ (50m wide and $15 \mathrm{~m}$ deep; Fournier et al. [2009]), and is therefore the second largest boiling lake in the world, after the Frying Pan Lake (New Zeeland) [Vandemeulebrouck et al. 2008]. The lake is hosted within a depression formed after a phreatic/phreato-magmatic explosion(s) [Joseph et al. 2011]. After the 1880 eruption [Sapper 1903, Robson and Willmore 1955, Brown 2002], the Boiling Lake has undergone prolonged phases of steady-state activity, in which the depression is filled by hot $\left(80\right.$ to $\left.90^{\circ} \mathrm{C}\right)$ and acidic (4-6) waters, and a vigorous gas upwelling region (object of this study) takes place in the lake's centre (Figure 1), forcing continuous turbulence and convection. This "steady-state" lake is characterized by highly saline (TDS up to $14.000 \mathrm{ppm}) \mathrm{Na}-\mathrm{Cl}\left(\mathrm{SO}_{4}\right)$ waters, which are thought to be deeply derived brines rising from a deep-seated hydrothermal reservoir, and which are variably admixed with (and diluted by) meteoric water [Joseph et al. 2011]. Apart from direct precipitations, the lake is fed by a stream on its northern shore; whilst the only visible outflow is on the southern shore, where lake waters overflow into the Rivière Blanche river [Fournier et al. 2009].

Heat, transferred to the lake via hydrothermal steam ascending through a central feeding conduit, sustains water convection observed in the centre of the lake, and maintains its temperature constant at $\sim 90^{\circ} \mathrm{C}$ [Fournier et al. 2009]. During their ascent, gas bubbles drag hot water with them and, compensating the hydrostatic pressure of the above water mass [Fournier et al. 2009], force the lake water to remain "suspended" $12-15 \mathrm{~m}$ above the local water table [Bardou 2006, Fournier et al. 2009], at least in the steady-state conditions. Condensed steam is then thought to be recycled back through the same conduit.

Since 1876 , occasional variations in lake activity (e.g., water level fluctuations and changes in the lake's chemical features) have been reported [Ober 1880, James 1988, Fournier et al. 2009], including a small lethal ( 2 casualties) explosion in 1901, causing the expulsions of $\mathrm{CO}_{2}$-rich gases into the atmosphere [Elliot 1938, Bell 1946]. Fournier et al. [2009] recently provided extensive report on the most recent lake's deviation from steady-state conditions. In this event, starting in December 2004, a significant drop in the water level was observed (until to nearly complete emptying of the lake), accompanied by a cessation of steam inflow into the lake and consequent temperature decrease (down to $20^{\circ} \mathrm{C}$ ). Several cycles of emptying-refilling, one of this lasting only one day, were observed in January 2005; during these events, low temperature, neutral, low-sulphate and low-chlorine waters were observed in the lake, with recurrent stopsrestarts of gas bubbling. This "crisis" eventually terminated in April 2005, when steady-state conditions in the lake (normal water level, high $\mathrm{T}-90^{\circ} \mathrm{C}$-, acid pH, and vigorous convection) were finally restored. No simultaneous change was reported in the neighboring hot springs and fumaroles of the Valley of Desolation.

Fournier et al. [2009] recently proposed a model in which the lake's drying out events would be triggered by external perturbations such as landslides and/or regional seismicity. These would result into a 
net decrease in gas flux into the lake, leading to fast downward flux of liquid water back into the conduit, and consequently (i) a significant reduction of the upward stress sustaining the water lake above the piezometric level, and (ii) drainage of the Boiling Lake down to the meteoric water table level. Afterwards, when the lake has entirely been empted, bubbles would return to rise up through the conduit and, dragging liquid water upwards, would promote refilling of the lake.

\section{Technique}

The highly dynamic degassing activity of the BL prevents any attempt to directly sample the vapours being released at the centre of the lake (Figure 1). Because of this, the compositional features of this gas have remained undetermined until this study. Clearly, a technique based on measurement of the lake atmospheric gas plume, rather than the hardly accessible fumaroles, is required.

The Multi-GAS, a custom-made instrument combining commercial gas sensors, is an increasingly used technique for accurate in-plume observations of volcanic gas species [Aiuppa et al. 2005, Shinohara 2005]. This instrument has traditionally been used to measure plume compositions at open-vent volcanoes, during surveys [e.g., Aiuppa et al. 2006, 2012], permanent installations [Aiuppa et al. 2007, 2009, 2010] or airborne profiling [Shinohara et al. 2003]. Two recent applications [Roberts et al. 2012, Shinohara et al. 2013]
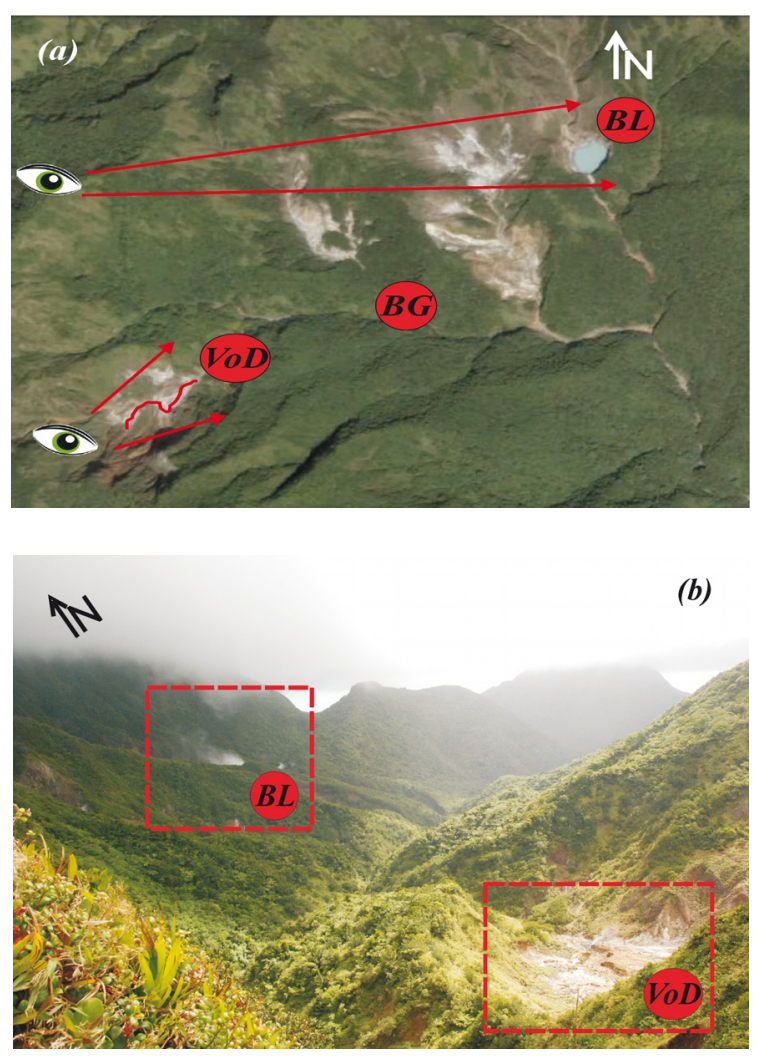
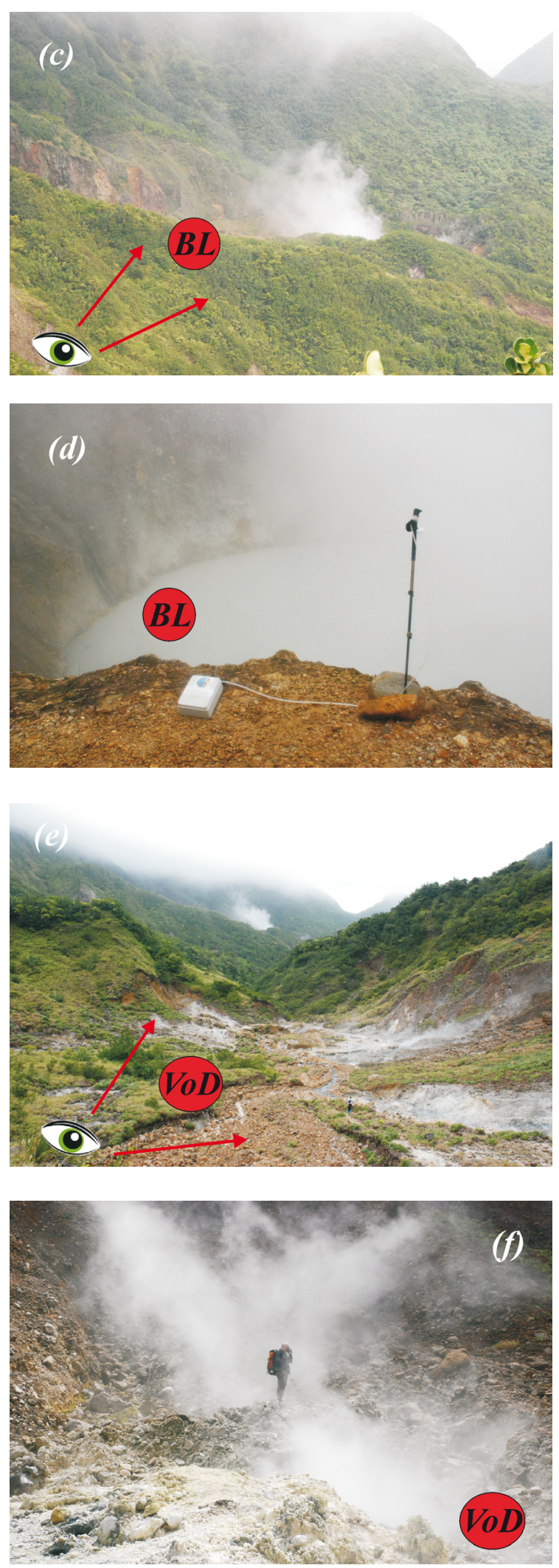

Figure 3. Image gallery from the Boiling Lake-Valley of Desolation area; (a) Google-Earth map of the study area (see Figure 2 for location); BL, VoD, and BG stand for measurement sites at Boiling Lake, Valley of Desolation, and at a background site (this site was remote enough from any visible manifestation); the track of the MultiGAS walking traverse made through and around the $\mathrm{VoD}$ fumarolic field is also shown (in red); (b, e) VoD and BL seen from south-west; (c) The Boiling Lake's plume seen from the west; (d) fixed-position measurements at BL; (f) the walking traverse at VoD. 
have first been demonstrated the ability of the MultiGAS to measurement of gas plumes issuing from a hot degassing volcanic lake (Yudamari crater lake, Aso volcano, Japan). This measurement approach is explored further here.

The portable Multi-GAS we used in this application allowed detection of the in-plume concentrations of $\mathrm{H}_{2} \mathrm{O}, \mathrm{CO}_{2}, \mathrm{SO}_{2}$ and $\mathrm{H}_{2} \mathrm{~S}$, using the following instrumental configuration (same as in recent studies; e.g., Aiuppa et al. [2011]): a Licor LI-840 NDIR closedpath spectrometer for $\mathrm{CO}_{2}$ and $\mathrm{H}_{2} \mathrm{O}$, and specific electrochemical sensors for $\mathrm{SO}_{2}(3 \mathrm{ST} / \mathrm{F}$ electrochemical sensor by City Technology Ltd.; 0-200 ppm range) and $\mathrm{H}_{2} \mathrm{~S}$ (EZ3H electrochemical sensor by City Technology Ltd.; 0-200 ppm range). All the sensors, powered by an internal battery, were housed in a water-proof box, through which the plume gas was pumped at 1.2 $1 /$ min rate. The sensor readouts were sampled at 0.5 $\mathrm{Hz}$ by an onboard data-logger, and saved into an internal memory board. The acquired data were postprocessed using the methodology described below (cf. Section 4).

Our measurements at the BL were taken on February 26, 2012, from a fixed position (Lat, N15.31867; Long, E61.2947; elevation 792m) on the north-northwestern outer rim of the depression hosting the lake (see Figures 1a and 3d). Weather conditions, which had remained unstable over the morning of February 26, significantly improved between mid-day and 3pm, when our observations were taken in relatively dry, stable (no precipitation, relative humidity of $\sim 70 \%$, $\mathrm{T}_{\text {ambient }}$ of $\sim 24^{\circ} \mathrm{C}$ ) conditions. The SSE winds, dominating on that day, brought the gases issuing from the lake's surface towards our observation site between about 1 and $1.50 \mathrm{pm}$ (local time). We estimate a plume travel time, from emission at the lake's surface to measurement at our observations site, of a few seconds at most, a far too short timescale for chemical processing in the plume to significantly alter the original fumarole composition. Tests made at a number of closed-conduit volcanoes in fumarolic stage of activity (e.g., La Fossa crater, Vulcano Island; Aiuppa et al. [2005]) have demonstrated fair agreement between Multi-GAS derived compositions of near-vent fumarolic atmospheric plumes and compositions of the source fumaroles (from direct sampling), at least for brief transport distances (timescales of tents of seconds).

In order to obtain consistent data to compare with our BL dataset, we also explored the fumarolic field of the Valley of Desolation (VoD). In this case, the technique was employed in a walking traverse mode [see Aiuppa et al. 2005], i.e., while traversing the fumarolic field with the MultiGAS transported in a backpack (Figure 3f). At each degassing vent, the traverse was stopped, and the instrument was left to acquire for a few minutes with its inlet being positioned at $\sim 0.5 \mathrm{~m}$ from the vent. Acquiring gas concentration data at $0.5 \mathrm{~Hz}$, and with simultaneous GPS positioning (Figure 3a), the Multi-GAS had the required tempo$\mathrm{ral} / \mathrm{spatial}$ resolution to map the chemical heterogeneity of a fumarolic field [e.g., Aiuppa et al. 2005]. Unfortunately in this specific VoD survey, however, the plume was condensing (e.g., liquid $\mathrm{H}_{2} \mathrm{O}$ was stable) close to most fumaroles (condensation occurred as steam cooled upon dilution and transport in air). In addition, both the $\mathrm{H}_{2} \mathrm{~S}$ and $\mathrm{CO}_{2}$ sensors achieved signal saturation (at $\sim 250 \mathrm{ppm}$ and $3500 \mathrm{ppm}$, respectively) in several part of the traverse. Only a subset of the acquired VoD dataset was therefore accessible to quantitative analysis.

\section{Results}

Figure 4 shows a 40 minute-long time-series of $\mathrm{H}_{2} \mathrm{O}, \mathrm{CO}_{2}, \mathrm{H}_{2} \mathrm{~S}$ and $\mathrm{SO}_{2}$ concentrations in the plume of the BL. For both $\mathrm{H}_{2} \mathrm{O}$ and $\mathrm{CO}_{2}$, we report in Figure 4 the air-corrected concentrations, which we calculated by subtracting from the raw measured concentrations the characteristic ambient air values of $22,300 \mathrm{ppm}$ and $385 \mathrm{ppm}$, respectively (obtained by averaging 10minute measurements in the background site BG shown in Figure 3a).

The figure demonstrates coherent temporal variations for in-plume concentrations of $\mathrm{H}_{2} \mathrm{O}, \mathrm{CO}_{2}$ and $\mathrm{H}_{2} \mathrm{~S}$, an hint for their common derivation from lake degassing. Visual observations during the measurements clearly suggest that the large and erratic concentration variations captured by the Multi-GAS reflected changes in plume direction and altitude (due to changes in wind speed and direction above the lake) and, only to a lesser extent, the time-changing dynamics of degassing of the lake. The peak concentrations $(3680,101$ and $25 \mathrm{ppm}$ for respectively $\mathrm{H}_{2} \mathrm{O}, \mathrm{CO}_{2}$ and $\mathrm{H}_{2} \mathrm{~S}$ ), evident in the central part of our record (at measurement number 600), were obtained in a (few-minutes long) temporary phase of wind speed decrease, during which the gas was forced to accumulate at our observation site. $\mathrm{SO}_{2}$, instead, was virtually absent in the plume, confirming that $\mathrm{H}_{2} \mathrm{~S}$ is the only $\mathrm{S}$ species emitted, and that no rapid oxidation process is occurring in the plume.

From the concentration data of Figure 4, the scatter plots of Figure 5 were obtained. These were then used to derive - by calculating the slopes of the best fit regression lines - the characteristic $\mathrm{CO}_{2} / \mathrm{H}_{2} \mathrm{~S}(5.2 \pm 0.4)$ and $\mathrm{H}_{2} \mathrm{O} / \mathrm{CO}_{2}(31 \pm 6)$ volatile ratios in the BL atmospheric plume (all ratios quoted here are molar).

Figures 4 and 5 compare the compositional feature 


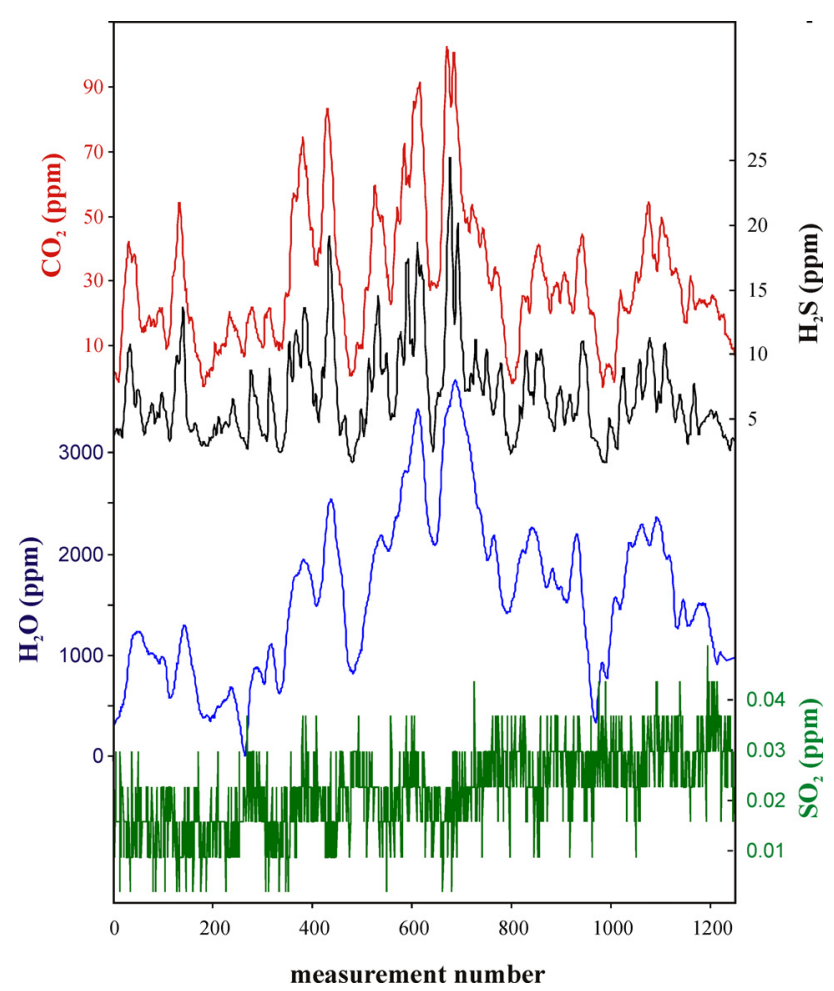

Figure 4. Time-series of gas concentrations in the near-vent plume of the Boiling Lake (taken at site BL; see Figures 1 and 3). A 40 minutes long record (with $0.5 \mathrm{~Hz}$ acquisition rate) is shown.

of the BL gas plume with the compositions of the atmospheric plumes of the VoD fumaroles (Figure 3). These latter were characterised by remarkably high $\mathrm{CO}_{2}(>3500 \mathrm{ppm})$ and $\mathrm{H}_{2} \mathrm{~S}(>250 \mathrm{ppm})$ concentrations, given the proximity $(50 \mathrm{~cm})$ of our measurements to the exhaling vents. Limiting our analysis to the couples of simultaneous measurements in which all sensors' outputs were below saturation (Figure 5a), we obtain a large spread of $\mathrm{CO}_{2} / \mathrm{H}_{2} \mathrm{~S}$, from $<2$ to $>50$, in agreement with large compositional variability observed in previous work [Joseph et al. 2011]. Most of the VoD fumaroles, however, converge at high gas concentrations to a $\mathrm{CO}_{2} / \mathrm{H}_{2} \mathrm{~S}$ of 5.7 , near our inferred composition for the BL. The VoD plumes were condensing close to most vents, precluding any $\mathrm{H}_{2} \mathrm{O}$ retrieval. Only at a few sites we obtained a volcanic signal clearly distinguishable from the atmospheric background, these measurements being summarised in Figure $5 \mathrm{c}$. From these, a representative $\mathrm{H}_{2} \mathrm{O} / \mathrm{CO}_{2}$ ratio of 20 is obtained for the VoD fumarolic field. The VoD fumarolic plumes also have very low but still detectable $\mathrm{SO}_{2}\left(\mathrm{SO}_{2} / \mathrm{H}_{2} \mathrm{~S}\right.$ of $\sim 0.00020$ ).

\section{Discussion}

The BL gas plume, for which we provide here the first compositional report (at least to our knowledge), is manifestly $\mathrm{H}_{2} \mathrm{O}$-rich $\left(\mathrm{H}_{2} \mathrm{O} / \mathrm{CO}_{2}\right.$ of $\left.31 \pm 6\right)$. With the objective of facilitating comparison between our observations and other volcanic gas datasets (Figure 6), we
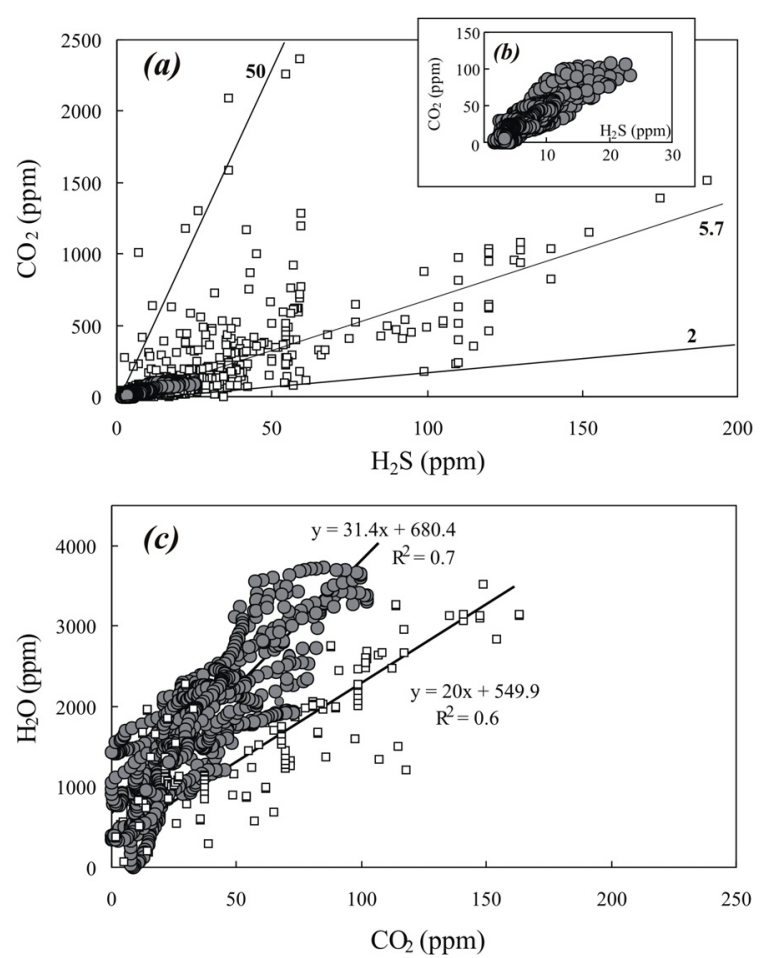

Figure 5. (a) $\mathrm{CO}_{2}$ vs. $\mathrm{H}_{2} \mathrm{~S}$ scatter plot for the Boiling Lake's gas plume (circles) and the Valley of Desolation's fumaroles' plumes (squares). The latter were acquired during a walking traverse through the fumarolic field (see Figure 3 for a track of the traverse); (b) A detail of (a); (c) a $\mathrm{H}_{2} \mathrm{O}$ vs. $\mathrm{CO}_{2}$ scatter plot (symbols as in (a)).

recalculated - from the plume characteristic ratios described above - an air-free composition for the BL gas. This operation, while mathematically correct, leads to a "real" volcanic gas composition only at condition that other volcanic gas species (not detected by the MultiGAS: e.g., $\mathrm{HCl}, \mathrm{CO}, \mathrm{H}_{2}, \mathrm{~N}_{2}$, etc.) are unimportant in the $\mathrm{BL}$ gas. This assumption, while not strictly true, is a good approximation, however, considering that $\mathrm{H}_{2} \mathrm{O}$, $\mathrm{CO}_{2}$ and $\mathrm{H}_{2} \mathrm{~S}$ generally make up $\sim 100 \%$ of the total gas phase in low-temperature hydrothermal gas manifestations [Chiodini and Marini 1998], including in Dominica [Joseph et al. 2011]. For instance, low concentrations of $\mathrm{HCl}$ ( $<24 \mathrm{mmol} / \mathrm{mol}), \mathrm{H}_{2}(<82 \mathrm{mmol} / \mathrm{mol}), \mathrm{N}_{2}(<116$ $\mathrm{mmol} / \mathrm{mol})$ and $\mathrm{CO}(<0.008 \mathrm{mmol} / \mathrm{mol})$ were reported by Joseph et al. [2011] for the VoD fumaroles, where $\mathrm{CO}_{2}$ and $\mathrm{H}_{2} \mathrm{~S}$ are normally in the hundreds of $\mathrm{mmol} / \mathrm{mol}$ range (all concentrations were reported by Joseph et al. [2011] on a dry-gas basis).

We finally obtained a recalculated composition for the $\mathrm{BL}$ gas of $\sim 96.3 \% \mathrm{H}_{2} \mathrm{O}, 3.1 \% \mathrm{CO}_{2}$ and $0.6 \% \mathrm{H}_{2} \mathrm{~S}$. This composition can now be used to better constrain the mechanisms of gas feeding to the BL. In their physical modelling study, Fournier et al. [2009] interpreted the $\mathrm{BL}$ as a suspended meteoric water body, heated by condensation of rising steam bubbles supplied (with eventually a brine component; Joseph et al. [2011]) by a deep hydrothermal reservoir. In such a model, two po- 


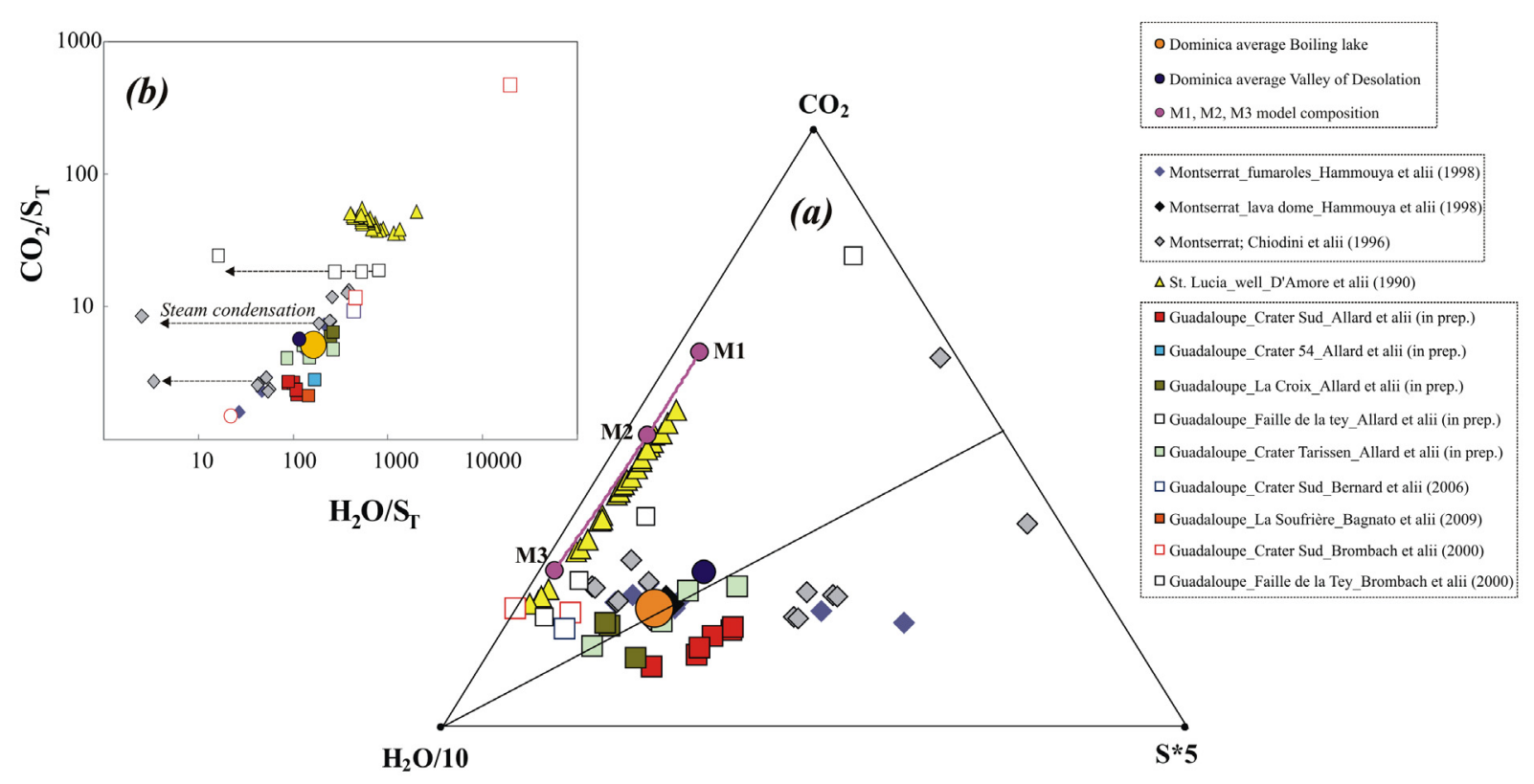

Figure 6. (a) A triangular plot putting the BL gas in the context of previous gas observations in the Lesser Antilles (see legend for references). Compositions for VoD and BL gases were obtained from the best-fit gas/gas ratios (e.g., from the slopes of the best-fit regression lines in Figure 5). The diagram also shows the compositions of M1-M3 model gases, obtained by EQ3 / 6 model simulations of gas lake-water interaction (scrubbing); (b) Scatter plot of $\mathrm{CO}_{2} / \mathrm{S}_{\mathrm{T}}$ vs. $\mathrm{H}_{2} \mathrm{O} / \mathrm{S}_{\mathrm{T}}$ ratios. The Boiling Lake gas sits in the median portion of the Lesser Antilles' gas population.

tential sources for our measured BL gas can be indentified: (i) the hydrothermal steam feeding the lake or (ii) evaporation/degassing of lake-water itself. Contribution (i) would of course be zero if steam was to completely condense into the lake before reaching its surface. With no BL gas measurements available, Fournier et al. [2009] were not in the condition to distinguish between hypotheses (i), (ii), or their combination. They however left the possibility open that, given the fast ascent of gas bubbles through a relatively thin shallow $(\sim 15 \mathrm{~m})$ lake, part of the supplied gas can make the whole path through the lake, to burst at its surface. Our measurements here open the way to testing the hypothesis.

\subsection{Models of gas-lake interaction and scrubbing}

Marini and Gambardella [2005] first used the EQ3 / 6 software (7.2b version; Wolery and Daveler [1992]) to quantitatively model interaction of a volcanic gas phase with an aqueous solution, and the consequent removal ("scrubbing") of water-soluble reactive gas species [Symonds et al. 2001]. Here, we follow the approach of Marini and Gambardella [2005] to model reaction between the BL lake-water and its feeding gas. Modelling is initialised and performed following the steps detailed below.

Step 1, Fixing feeding gas composition - The composition of the gas supplying the lake from below is unknown, but is required to initialise a simulation of gas scrubbing. Given the proximity between $\mathrm{BL}$ and VoD, we can make the guess that the composition of the feeding gas is approximated by a VoD-type gas. This latter is evaluated at $\sim 94.4 \% \mathrm{H}_{2} \mathrm{O}, 4.7 \% \mathrm{CO}_{2}, 0.8 \% \mathrm{H}_{2} \mathrm{~S}$, and $0.1 \mathrm{HCl} \%$, using our $\mathrm{H}_{2} \mathrm{O} / \mathrm{CO}_{2}(20)$ and $\mathrm{CO}_{2} / \mathrm{H}_{2} \mathrm{~S}$ (5.7) ratios (cf. Section 4), and assuming an average $\mathrm{H}_{2} \mathrm{~S} / \mathrm{HCl}$ ratio of 13 (the mean ratio calculated from the dataset of Joseph et al. [2011]). The temperature of the feeding gas, prior to its entrance in the lake, is taken at $200{ }^{\circ} \mathrm{C}$ (the equilibrium temperature estimated from application of the $\mathrm{Na} / \mathrm{K}$ aqueous geothermometer to $\mathrm{BL}$ lake-water; Joseph et al. [2011]). Tests made changing this temperature range (in the $100-200{ }^{\circ} \mathrm{C}$ ) demostrated no substantial effect on the simulations.

Step 2, Fixing meteoric water composition - The composition of the meteoric water component entering the $\mathrm{BL}$, and therein interacting with the feeding gas, is also required as initial solution for the simulations. No such data is reported in Fournier et al. [2009] and Joseph et al. [2011]. We therefore selected, as a proxy for the meteoric water entering the $\mathrm{BL}$, the composition of a cold $\left(\mathrm{T}=23^{\circ} \mathrm{C}\right)$ spring water from Soufrière volcano, in nearby Guadeloupe island (sample Beaugendre, from Brombach et al. [2000]).

Step 3, EQ3/6 runs - We then numerically simulated the gas-water interaction process by running a set of isothermal model calculations with EQ3/6. We performed 3 separate runs, having the same feeding gas and 
initial aqueous solution (steps 1-2 above), but differing for the mole amounts of feeding gas allowed to interact with $1 \mathrm{~kg}$ of initial solution. These were increased in the sequence 5.5, 6.4 and 7.2 moles (per kg of initial solution) from run 1 to 3 . The temperature of the 3 runs were then determined by a simple enthalpy balance between the feeding gas $\left(200{ }^{\circ} \mathrm{C}\right)$ and the initial solution $\left(23^{\circ} \mathrm{C}\right)$, and increased in the succession $84^{\circ} \mathrm{C}(5.5$ moles added), $92{ }^{\circ} \mathrm{C}$ ( 6.4 moles added) and $99^{\circ} \mathrm{C}$ ( 7.2 moles added). The most "gas-rich" run we performed, therefore obtained by adding 7.2 moles of feeding gas to $1 \mathrm{~kg}$ of initial water, was then representative of the heating process of the initial solution, from its original temperature $\left(23^{\circ} \mathrm{C}\right)$ up to boiling temperature $\left(99^{\circ} \mathrm{C}\right)$. In each of the 3 runs, the code output consisted in the equilibrium composition of dissolved aqueous species in the model solution, including the partial pressures of individual gas species.

Step 4, degassing - At the end of each of the 3 runs, the total pressure of dissolved gases (calculated by summing together partial pressures of individual gas species) exceeded 1 bar. The obtained model solutions were then degassed using a single-step degassing model [see Marini and Gambardella 2005], until 1 bar total gas pressure was obtained. The so-derived model gas phase compositions (M1 to M3), obtained via degassing of model solutions, are shown, for the different runs, in the triangular diagram of Figure 6.

The model gases M1 to M3 (Figure 6) are ultimately representative of the gas that would form by degassing of (gas separation from) the BL at $84{ }^{\circ} \mathrm{C}, 92{ }^{\circ} \mathrm{C}$ and $99{ }^{\circ} \mathrm{C}$. Model gas compositions M1-M3 are clearly distinct, for manifestly being depleted in sulphur $\left(\mathrm{CO}_{2} / \mathrm{H}_{2} \mathrm{~S}\right.$ ratios of 11-17), from the feeding gas composition (VoD gas; $\left.\mathrm{CO}_{2} / \mathrm{H}_{2} \mathrm{~S}=5.7\right)$. This mismatch demonstrates the "chemical filtering" effect potentially played by gas-water interaction, in which more water-soluble $\mathrm{H}_{2} \mathrm{~S}$ is preferentially (relative to $\mathrm{CO}_{2}$ ) scrubbed out of the feeding gas, and oxidised to dissolved sulphate (model solutions have dissolved sulphate contents of 3500-4950 mg/1, comparable to those reported for the BL by Joseph et al. [2011]). This gas scrubbing process also acts to remove $\mathrm{HCl}$ from the feeding gas: M1-M3 gas compositions are virtually $\mathrm{HCl}$-free, since all $\mathrm{Cl}$ available in the model runs is transferred into model solutions (having dissolved $\mathrm{Cl}$ contents of $135-180 \mathrm{mg} / \mathrm{l})$. The $\mathrm{H}_{2} \mathrm{O} / \mathrm{CO}_{2}$ ratio of model gases depends on temperature, with the M3 gas (formed by evaporation of the lake at the highest modelled temperature of $99^{\circ} \mathrm{C}$ ) being the most $\mathrm{H}_{2} \mathrm{O}$-rich.

Our observed BL gas is chemically distinct from M1-M3 model gases (Figure 6). We argue therefore that the BL gas can not be formed by lake evaporation/degassing (e.g., from gases originally dissolved in the lake- water) - was this the case, a far more S-depleted composition (similar M1-M3 gases) should have been detected by the Multi-GAS. We note, instead, that the BL gas is compositionally very similar (only slightly more $\mathrm{H}_{2} \mathrm{O}$-rich) to the VoD gas (the feeding gas in our simulations). We conclude, therefore, that only a (minor) part of the feeding gas is scrubbed by condensation/reaction into the lake, with the remaining fraction being free to escape through the lake surface to feed the BL plume. This incomplete feeding gas scrubbing likely reflects the rapid, vigorous ascent of gas bubbles through the lake (Figure 1).

\subsection{The BL gas in a regional context}

If, as proposed above, the BL gas is only marginally affected by scrubbing in the lake, comparison is then possible with available volcanic gas datasets in the region. Figure 6 puts our Dominica measurements in the context of published gas analyses from active volcanoes in the Lesser Antilles.

Research on volcanic gas compositional signature in the Lesser Antilles arc has received significant impetus after the 1995-present eruption of Soufrière Hills (Montserrat); still, the available information remains fragmentary and incomplete - at least relative to other better characterised arc regions [Hilton et al. 2002, Mather et al. 2006, Fischer 2008]. The high-temperature $\left(>700^{\circ} \mathrm{C}\right)$ gas emissions issuing from the Soufrière Hills dome should in principle represent a source of invaluable information to constrain the truly magmatic gas composition in the region. However, given the inaccessibility of the vent area, and our current technical limitations in remotely sensing the major $\left(\mathrm{H}_{2} \mathrm{O}\right.$ and $\left.\mathrm{CO}_{2}\right)$ gas species, it is only the $\mathrm{SO}_{2}$ volatile budget to remain well characterised [see Christopher et al. 2010, and references therein]; the $\mathrm{C} / \mathrm{S}$ gas signature (and consequently the $\mathrm{CO}_{2}$ fluxes) have only recently been established [Edmonds et al. 2010], instead, and the $\mathrm{H}_{2} \mathrm{O}$ flux remains unconstrained. There has been, however, one fortunate report [Hammouya et al. 1998] of gas collection on-top Soufrière Hills dome on February 1996 (just before pyroclastic flows started); the collected gas samples, while affected by air dilution, allowed to set the recalculated (on air-free basis) magmatic gas composition at $\sim 91 \%$ $\mathrm{H}_{2} \mathrm{O}, \sim 3 \% \mathrm{CO}_{2}, 2.7 \% \mathrm{HCl}$ and $0.6 \%$ total sulphur (mainly present as $\mathrm{SO}_{2}$ ). This Hammouya's et alii [1998] $\mathrm{H}_{2} \mathrm{O}-\mathrm{CO}_{2}$-S magmatic gas composition for Soufrière Hills (e.g., with $\mathrm{HCl}$ not being considered) is close our above-derived composition for the Boiling Lake (Figure 6). Soufrière Hills and BL gases show, for instance, nearly identical $\mathrm{CO}_{2} / \mathrm{S}_{\mathrm{T}}$ ratios of 5.1 and 5.2, respectively.

The ongoing (1992-present) degassing crisis of La Soufrière dome (references in Bernard et al. [2006]) 
makes of nearby Guadeloupe Island the second most significant volcanic gas spot in the region. Here again, however, the number of published gas reports is relatively small [e.g., Brombach et al. 2000, Bernard et al. 2006, Ruzié et al. 2012]. When this previous dataset is combined with results of our recent Multi-GAS observations in March 2012 [Allard et al. 2013] the Soufrière of Guadeloupe volcanic gases display an almost linear compositional array, from the S-poor $\left(\mathrm{CO}_{2} / \mathrm{S}_{\mathrm{T}}\right.$ of 11 474) compositions reported for the early 1997 activity by Brombach et al. [2000] (samples collected just prior degassing activity increased in vigour in December 1997) to the S-rich $\left(\mathrm{CO}_{2} / \mathrm{S}_{\mathrm{T}}\right.$ of $\left.\sim 2.5\right)$ we observed on March 2012 [Allard et al. 2013], and which are representative of the ongoing degassing crisis. Notably, our BL gas sits in the central part of the Soufrière of Guadeloupe array.

The overall good match between the BL gas composition and more "truly magmatic" fluids in the region (e.g., Soufrière Hills and La Soufrière dome) once more supports the conclusion of a minor role played by secondary processes (e.g., gas scrubbing) in the lake.

\section{Conclusive remarks}

We have presented here the first chemical characterization of volcanic gas release at the Boiling Lake, one of the most prominent hydrothermal-volcanic manifestations in Dominica, and in the entire Lesser Antilles arc. Our results support a clearly volcanic derivation for the $\mathrm{BL}$ gas, and a marginal role played by interaction with lake waters (gas scrubbing). Our observations also provide additional confidence [Roberts et al. 2012, Shinohara et al. 2013] on the ability of the Multi-GAS to operate in the harsh conditions (e.g., very high relative humidity) often encountered in the plume(s) issuing from active volcanic lakes. At least in the conditions met during our survey, the BL plume was "dry" enough for volcanic $\mathrm{H}_{2} \mathrm{O}$ sensing (which is hampered by liquid water if present in substantial amounts), and "dense" enough for a significant volcanic signal to be resolved from the background. We conclude that this technique could valuably assist any future plan for monitoring of the BL activity. Given the relatively frequent record of harmful volcanic events (phreatic explosions, and sudden toxic gas release events) in the recent past, and the increasing visitors inflow in Dominica, implementation of the monitoring network (including gas chemistry) should be a priority of local authorities and hazard managers in the region.

Acknowledgements. The staff of the Crescent Moon Cabins (Dominica), and especially the local guide David, are particularly acknowledged for their logistic support to field work. We wish to thank Dr. D. Rouwet and anonymous Reviewer for constructive comments. This research was funded by Miur-UniPa (A.A., R.D.N) and research contract ANR DOMOSCAN 08-RISKNAT-002-01 (P.A. and A.A.). The research leading to these results has also received funding from the european research council under the European Union's Seventh Framework Programme (FP7/2007/2013)/ERC grant agreement n1305377.

\section{References}

Aiuppa, A., C. Federico, G. Giudice, and S. Gurrieri (2005). Chemical mapping of a fumarolic field: La Fossa Crater, Vulcano Island (Aeolian Islands, Italy), Geophys. Res. Lett., 32; doi:10.1029/2005GL023207.

Aiuppa, A., C. Federico, G. Giudice, S. Gurrieri, M. Liuzzo, H. Shinohara, R. Favara and M. Valenza (2006). Rates of carbon dioxide plume degassing from Mount Etna volcano, J. Geophys. Res., 111; doi:10.1029/2006JB004307.

Aiuppa, A., R. Moretti, C. Federico, G. Giudice, S. Gurrieri, M. Liuzzo, P. Papale, H. Shinohara and M. Valenza (2007). Forecasting Etna eruptions by realtime observation of volcanic gas composition, Geology, 35, 1115-1118; doi:10.1130/G24149A.

Aiuppa, A., C. Federico, G. Giudice, G. Giuffrida, R. Guida, S. Gurrieri, M. Liuzzo, R. Moretti and P. Papale (2009). The 2007 eruption of Stromboli volcano: Insights from real-time measurement of the volcanic gas plume $\mathrm{CO}_{2} / \mathrm{SO}_{2}$ ratio, J. Volcanol. Geoth. Res., 182, 221-230; doi:10.1016/j.jvolgeores. 2008.09.013.

Aiuppa, A., A. Bertagnini, N. Métrich, R. Moretti, A. Di Muro, M. Liuzzo and G. Tamburello (2010). A model of degassing for Stromboli volcano, Earth Planet. Sci. Lett., 295, 195-204.

Aiuppa, A., H. Shinohara, G. Tamburello, G. Giudice, M. Liuzzo and R. Moretti (2011). Hydrogen in the gas plume of an open-vent volcano, Mount Etna, Italy, J. Geophys. Res., 116; doi:10.1029/2011JB008461.

Aiuppa, A., G. Giudice, M. Liuzzo, G. Tamburello, P. Allard, S. Calabrese, I. Chaplygin, A. J. S. McGonigle and Y. Taran (2012). First volatile inventory for Gorely volcano, Kamchatka, Geophys. Res. Lett., 39; doi:10.1029/2012GL051177.

Allard, P., A. Aiuppa, F. Beauducel, D. Gaudin, R. Di Napoli, O. Crispi, S. Calabrese, F. Parello, G. Hammouya and G. Tamburello (2013). Steam and gas emission rate from La Soufrière volcano, Guadeloupe (Lesser Antilles): implications for the magmatic-hydrothermal fluid supply during a period of degassing unrest, Chem. Geol., sub judice.

Bagnato, E., P. Allard, F. Parello, A. Aiuppa, S. Calabrese and G. Hammouya (2009). Mercury gas emissions from La Soufrière Volcano, Guadeloupe Island (Lesser Antilles), Chem. Geol., 266, 267-273.

Bardou, L. (2006). Etude d'un lac volcanique: Le Boiling 
Lake, M.Sc. thesis, Univ. Paul Sabatier, Toulouse, France.

Bell, H. (1946). Glimpses of a Governor's Life - Dominica, Samson Low, London.

Bellon, H. (1988). Reconnaissance chronologique des deux premieres phases d'activite volcanique en Dominique (Petites Antilles), C.R. Acad. Sci, Paris, 306, 1487-1492.

Bernard, M. L., J. Molinié, R-H Petit, F. Beauducel, G. Hammouya and G. Marion (2006). Remote and in situ plume measurements of acid gas release from La Soufrière volcano, Guadeloupe, J. Volcanol. Geoth. Res., 150, 395-409.

Bouysse, P. (1984). The Lesser Antilles island arc: structure and geodynamic evolution, Initial Reports DSDP 78, US Govt. Printing Office, Washington, 83-103.

Bouysse, P., D. Westercamp and P. Andreieff (1990). The Lesser Antilles Island Arc, In: J. C. Moore, A. Mascle et al. (eds.), Proceedings of the Ocean Drilling Program, Scientific Results, 110, 29-44.

Brombach, T., L. Marini and J. C. Hunziker (2000). Geochemistry of the thermal springs and fumaroles of Basse-Terre Island, Guadeloupe, Lesser Antilles, Bull. Volcanol., 61, 477-490.

Brown, G. M., J. G. Holland, H. Sigurdsson, J. F. Tomblin and R. J. Arculus (1977). Geochemistry of the Lesser Antilles volcanic island arc, Geochim. Cosmochim. Acta, 41, 785-801.

Brown, L. (2002). Gas Geochemistry of the Volcanic Hydrothermal Systems of Dominica and St. Lucia, Lesser Antilles: implications for volcanic monitoring, University of New Mexico, Unpublished senior honors thesis.

Carey, S. N., and H. Sigurdsson (1980). The Roseau ash: Deep-sea tephra deposits from a major eruption on Dominica, Lesser Antilles arc, J. Volcanol. Geoth. Res., 7, 67-86.

Chiodini, G., and L.Marini (1988). Hydrothermal gas equilibria: The $\mathrm{H}_{2} \mathrm{O}-\mathrm{H}_{2}-\mathrm{CO}_{2}-\mathrm{CO}-\mathrm{CH}_{4}$ system, Geochim. Cosmochim. Acta, 62, 2673-2687.

Chiodini, G., R. Cioni, A. Frullani, M. Guidi, L. Marini, F. Prati and B. Raco (1996). Fluid geochemistry of Montserrat Island, West Indies, Bull. Volcanol., 58, 380-392.

Christopher, T., M. Edmonds, M. C. S. Humphreys and R. A. Herd (2010). Volcanic gas emissions from Soufrière Hills Volcano, Montserrat 1995-2009, with implications for mafic magma supply and degassing, Geophys. Res. Lett., 37; doi:10.1029/2009GL041325.

D’Amore, F., J. R. Rivera, D. Giusti and R. Rossi (1990). Preliminary geochemical and thermodynamic assessment of the geothermal resources, Sulphur Springs area, St Lucia, W.I., Appl. Geochem., 5, 587-604.
Davidson, J. P. (1985). Mechanisms of contamination in Lesser Antilles island arc magmas from radiogenic and oxygen isotope relationships, Earth Planet. Sci. Lett., 72, 163-174.

Davidson, J. P. (1986). Isotopic and trace element constraints on the petrogenesis of subduction-related lavas from Martinique, Lesser Antilles, J. Geophys. Res., 91, 5943-5962.

Davidson, J. P. (1987). Crustal contamination versus subduction zone enrichment: examples from the Lesser Antilles and implications for mantle source compositions of island arc volcanic rocks, Geochim. Cosmochim. Acta, 51, 2185-2198.

Demange, J., H. Leborne, H. Traineau and D. Westercamp (1985). Histoire volcano-structurale de la Region sud de la Dominique. Bureau de Recherches Geologiques et Minieres (BRGM), Institut Mixte de Recherches Geothermiques, Rapport 85 SGN 068 IRG-GTH, $114 \mathrm{pp}$.

DeMets, C., P. E. Jansma, G. S. Mattioli, T. H. Dixon, F. Farina, R. Bilham, E. Calais and P. Mann (2000). GPS geodetic constraints on Caribbean-North America plate motion, Geophys. Res. Lett., 27, 437-440.

Dixon, T. H., F. Farina, C. DeMets, P. Jansma, P. Mann and E. Calais (1998). Relative motion between the Caribbean and North American plates and related boundary zone deformation from a decade of GPS observations, J. Geophys. Res., 103, 15157-15183.

Druitt, T. H., S. R. Young, B. Baptie, C. Bonadonna, E. S. Calder, A. B. Clarke, P. D. Cole, C. L. Harford, R. A. Herd, R. Luckett, G. Ryan and B. Voight (2002). Episodes of cyclic Vulcanian explosive activity with fountain collapse at Soufrière Hills Volcano, Montserrat, In: T. H. Druitt and B. P. Kokelaar (eds.), The Eruption of Soufrière Hills Volcano, Montserrat, from 1995 to 1999, Geol. Soc. London Mem., 21, 281-306.

Edmonds, M., A. Aiuppa, M. Humphreys, R. Moretti, G. Giudice, R. S. Martin, R. A. Herd and T. Christopher (2010). Excess volatiles supplied by mingling of mafic magma at an andesite arc volcano, Geochem. Geophys. Geosyst., 11; doi:10.1029/2009GC 002781.

Elliot, E.C. (1938). Boiling Lake - the 1900 Story, In: G. Bless (ed.), Broken Atoms.

Feuillet, N., I. Manighetti and P. Tapponnier (2002). Arc parallel extension and localization of volcanic complexes in Guadeloupe Lesser Antilles, J. Volcanol. Geoth. Res., 107; doi:10.1029/2001JB000308.

Fischer, T. P. (2008). Fluxes of volatiles $\left(\mathrm{H}_{2} \mathrm{O}, \mathrm{CO}_{2}, \mathrm{~N}_{2}\right.$, $\mathrm{Cl}, \mathrm{F})$ from arc volcanoes, Geochem. Internat., 42, 21-38.

Fournier, N., F. Witham, M. Moreau-Fournier and L. 
Bardou (2009). The Boiling Lake of Dominica, West Indies: high temperature volcanic crater lake dynamics, J. Volcanol. Geoth. Res., 114; doi:10.1029/ 2008JB005773.

James, A. (1988). A cool Boiling Lake?, The New Chron. (Dominica), June, Dominica, W. I.

Joseph, E. P., N. Fournier, J. M. Lindsay and T. P. Fischer (2011). Gas and water geochemistry of geothermal systems in Dominica, Lesser Antilles island arc, J. Volcanol. Geoth. Res., 206, 1-14.

Hammouya, G., P. Allard, P. Jean-Baptiste, F. Parello, M. P. Semet and S. R. Young (1998). Pre- and syn-eruptive geochemistry of volcanic gases from Soufrière Hills of Montserrat, West Indies, Geophys. Res. Lett., 25, 3685-3688; doi:10.1029/98GL02321.

Hawkesworth, C. J., and M. Powell (1980). Magma genesis in the Lesser Antilles island arc, Earth Planet. Sci. Lett., 45, 297-308.

Hilton, D. R., T. P. Fischer and B. Marty (2002). Noble gases and volatile recycling in subduction zones, In: D. Porcelli, C. Ballentine and R. Weiler (eds.), Reviews in mineralogy and geochemistry, Min. Soc. of America, Washington, DC, 47, 319-370.

Komorowski, JC., G. Boudon, M. Semet, F. Beauducel, C. Antenor-Habazac, S. Bazin and G. Hammouya (2005). Guadeloupe, In: J. M. Lindsay, R. E. A. Robertson, J. B. Shepherd and S. Ali (eds.), Volcanic Hazard Atlas of the Lesser Antilles, Seismic Research Unit, The University of the West Indies, Trinidad and Tobago, West Indies, 67-105.

Lacroix, A. (1904). La Montagne Pelée et ses eruptions, Masson et cie, Paris, 662 pp.

Lindsay, J. M., M. V. Stasiuk and J. B. Shepherd (2003). Geological history and potential hazards of the latePleistocene to Recent Plat Pays volcanic complex, Dominica, Lesser Antilles, Bull. Volcanol., 65, 201-220.

Lindsay, J.M., A.L. Smith, M.J. Roobol and M.V. Stasiuk (2005). Dominica, In: J.M. Lindsay, R.E.A. Robertson, J.B. Shepherd and S. Ali (eds.), Volcanic Hazard Atlas of the Lesser Antilles, Seismic Research Unit, The University of the West Indies, Trinidad and Tobago, West Indies, 1-48.

Marini, L., and B. Gambardella (2005). Geochemical modeling of magmatic gas scrubbing, Annals of Geophysics, 48, 739-753.

Martin-Kaye, P. H. A. (1969). A summary of the geology of the Lesser Antilles, Overseas Geology and Mineral Resources, 10, 172-206.

Mather, T. A., D. M. Pyle, V. I. Tsanev, A. J. S. McGonigle, C. Oppenheimer and A. G. Allen (2006). A reassessment of current volcanic emissions from the Central American arc with specific examples from Nicaragua, J. Volcanol. Geoth. Res., 149, 297-311.
Maury, R. C., G. K. Westbrook, P. E. Baker, P. Bouysse and D. Westercamp (1990). The Lesser Antilles, In: G. Dengo and J. Case (eds.), Decade of North American Geology, H, The Caribbean Region, Geological Society America, 141-166.

Monjaret, M. C. (1985). Contribution a l'étude de l'arc des Petites Antilles. Le Volcanisme de la Dominique. Données chronologiques, mineralogiques et geochimiques, Unpublished thesis, Université de Bretagne Occidentale, $77 \mathrm{pp}$.

Nicholls, H. A. A. (1880a). The volcanic eruption in Dominica, Nature, 21, 372-373.

Nicholls, H. A. A. (1880b). Visit to the scene of the late volcanic eruption, The Dominican, 17 January 1880.

Ober, F. A. (1880). Camps in the Caribbees: The Adventures of a Naturalist in the Lesser Antilles, Douglas, Edinburgh, UK.

Pedroni, A., K. Hammerschmidt and H. Friedrichsen (1999). $\mathrm{He}, \mathrm{Ne}, \mathrm{Ar}$, and C isotope systematics of geothermal emanations in the Lesser Antilles Islands Arc, Geochim. Cosmochim. Acta, 63, 515-532.

Roberts, T. J., C. F. Braban, C. Oppenheimer, R. S. Martin, R. A. Freshwater, D. H. Dawson, P. T. Griffiths, R. A. Cox, J. R. Saffell and R. L. Jones (2012). Electrochemical sensing of volcanic gases, Chem. Geol., 332-333, 74-91.

Robson, G. R., and P. L. Willmore (1955). Some heat measurements in West Indian Soufriéres, Bull. Volcanol., 17,13-39.

Roobol, M.J., and Smith A.L. (1989). Volcanic and associated hazards in the Lesser Antilles, In: J. H. Latter (ed.), Volcanic Hazards - Assessment and Monitoring, Springer-Verlag, Berlin, 57-85.

Roobol, M.J., and A.L. Smith (2005). Geological Map of Dominica, scale 1:100,000, In: J. M. Lindsay, R. E. A. Robertson, J. B. Shepherd and S. Ali (eds.), Volcanic Hazard Atlas of the Lesser Antilles, University of the West Indies.

Ruiz, M., A. Galve, T. Monfret, M. Sapin, P. Charvis, M. Laigle, M. Evain, A. Hirn, E. Flueh, J. Gallart, J. Diaz, J.F. Lebrun and Antilles Thales scientific party (2011). Seismic activity offshore Martinique and Dominica islands (Central Lesser Antilles subduction zone) from temporary onshore and offshore seismic networks, Tectonophysics; doi:10.1016/j.tecto.2011. 08.006 .

Ruzié, L., M. Moreira and O. Crispi (2012). Noble gas isotopes in hydrothermal volcanic fluids of $\mathrm{La}$ Soufrière volcano, Guadeloupe, Lesser Antilles arc, Chem. Geol., 304-305, 158-165.

Sapper, K. (1903). Ein besuch von Dominica, Zent. Mineral. Geol. Paleontol., 305-314.

Shinohara, H., K. Kazahaya, G. Saito, K. Fukui and M. 
Odai (2003). Variation of $\mathrm{CO}_{2} / \mathrm{SO}_{2}$ ratio in volcanic plumes of Miyakejima: Stable degassing deduced from heliborne measurements, Geophys. Res. Lett., $30,12-1$.

Shinohara, H. (2005). A new technique to estimate volcanic gas composition: plume measurements with a portable multi-sensor system, J. Volcanol. Geoth. Res., 143, 319-333.

Shinohara, H., S. Yoshikawa and Y. Miyabuchi (2013). Degassing activity of a volcanic crater lake: Volcanic plume measurements at the Yudamari crater lake, Aso volcano, Japan; accepted for publication in: D. Rouwet, F. Tassi, J. Vandemeulebrouck (eds.), Volcanic Lakes, Advances in Volcanology, Springer.

Sigurdsson, H. (1972). Partly-welded pyroclast flow deposits in Dominica, Lesser Antilles, Bull. Volcanol., 36, 148-163.

Sigurdsson, H., J. F. Tomblin, G. M. Brown, J. G. Holland and R. J. Arculus (1973). Strongly undersaturated magmas in the Lesser Antilles Island Arc, Earth Planet. Sci. Lett., 18, 285-295.

Smith, A. L., M. J. Roobol and B. Gunn (1980). The Lesser Antilles: a discussion of Island Arc Volcanism, Bull. Volcanol., 43, 287-302.

Smith, T. E., M. F. Thirlwall and C. G. Macpherson (1996). Trace element and isotope geochemistry of the volcanic rocks of Bequia, Grenadine Islands, Lesser Antilles arc: a study of subduction enrichment and intra-crustal contamination, J. Petrol., 37, 117-143.

Sparks, R. S. J., H. Sigurdsson and S. N. Carey (1980). The entrance of pyroclastic flows into the sea, I. Oceanographic and geologic evidence from Dominica, Lesser Antilles, J. Volcanol. Geoth. Res., 7, 87-96.

Stasiuk, M. V., J. B. Shepherd, J. Latchman and J. M. Lindsay (2002). Intrusion-induced caldera fault slip imaged by shallow seismicity on Dominica, West Indies, 1998-2000, Seismol. Res. Lett., 73, 242.

Symonds, R. B., W. I. Rose, G. J. S. Bluth and T. M. Gerlach (1994). Volcanic-gas studies: methods, results and applications, In: M. R. Carroll and J. R. Holloway (eds.), Volatiles in magmas, Rev. Mineral., 30, Mineral. Soc. of Am., Washington, 1-66.

Symonds, R. B., T. M. Gerlach and M. H. Reed (2001). Magmatic gas scrubbing: implications for volcano monitoring, J. Volcanol. Geotherm. Res., 108, 303341.

Thirlwall, M. F., A. M. Graham, R. J. Arculus, R. S. Harmon and C. G. Macpherson (1996). Resolution of the effects of crustal assimilation, sediment subduction, and fluid transport in island arc magmas: $\mathrm{Pb}-\mathrm{Sr}-\mathrm{Nd}-\mathrm{O}$ isotope geochemistry of Grenada, Lesser Antilles, Geochim. Cosmochim. Acta, 60,
4785-4810.

Vandemeulebrouck, J., A.W. Hurst and B.J. Scott (2008). The effects of hydrothermal eruptions and a tectonic earthquake on a cycling crater lake (Inferno Crater Lake, Waimangu, New Zealand). J. Volcanol. Geotherm. Res., 178, 271-275.

Wadge, G. (1984). Comparison of volcanic production rates and subduction rates in the Lesser Antilles and Central America, Geology, 12, 555-558.

Wadge, G., and J. B. Shepherd (1984). Segmentation of the Lesser Antilles subduction zone, Earth. Planet. Sci. Lett., 71, 297-304.

Westercamp, D. (1988). Magma generation in the Lesser Antilles: geological constraints, Tectonophysics, 149, 145-163.

White, W. M., and B. Dupré (1986). Sediment subduction and magma genesis in the Lesser Antilles; isotopic and trace element constraints, J. Geophys. Res., 91, 5927-5941.

Wolery, T. J., and S.A. Daveler (1992). EQ6, a computer program for reaction path modeling of aqueous geochemical systems: theoretical manual, user's guide and related documentation (version 7.0), Report UCRl-MA-110662 PT IV, Lawrence Livermore National Laboratory, Livermore, California.

\footnotetext{
${ }^{\star}$ Corresponding author: Rossella Di Napoli, Università degli Studi di Palermo, Dipartimento di Scienze della Terra e del Mare (DiSTeM), Palermo, Italy; email: rossella.dinapoli@unipa.it.

C 2013 by the Istituto Nazionale di Geofisica e Vulcanologia. All rights reserved.
} 